\title{
MORAL HAZARD DAN AGENCY COST (Pencederaan Kontrak Bisnis dalam Perspektif Ekonomi Syarî'ah)
}

\author{
Wadhan \\ (Dosen Jurusan Tarbiyah STAIN Pamekasan)
}

\begin{abstract}
:
A contract for business organization or production process may generally involve Principal- agent problems due to information asymetry. Islâmic business contracts has manifold avenues and modalities to be implemented as according to the suitability of time, place and environment.The essential benefits of the Islâmic business contracts is to ensure the benefit of the both partners in the contract. Since the contract for business organization or production process embodies some sort of problems like principal- agent problem due to information asymetry and moral hazard, this also be easily minimised in an Islâmic contract. Therefore, it may be said that if in an Islâmic economy, Islâmic firm implements the business contract as designed and approved by the shariah, then principal- agent problem will be minimised and society will be more benefited from the welfare motive of the producer and other market agents.
\end{abstract}

\section{Keywords:}

Moral hazard, agency cost, asymetry information, dan agent.

\section{Pendahuluan.}

Al-Qur'ân merupakan sumber utama ajaran Islâm telah menetapkan erbagai aturan sebagai hidâyah (petunjuk) bagi umat manusia dalam melakukan aktivitas di setiap aspek kehidupannya, termasuk di bidang ekonomi. ${ }^{1}$ Ini menunjukkan bahwa janji atau

1Lihat, misalnya, QS. al-Nisâ': 29, al-An'âm: 119, dan al-Mâ'idah: 1. 
kontrak itu wajib dilaksanakan tanpa kecuali dan kontrak itu tidak akan mengikat kecuali dilaksanakan secara betul dan sah. Kontrak bisnis Islâm memiliki banyak bidang dan modalitas untuk diterapkan menurut kecocokan waktu, tempat dan lingkungan. Manfaat yang penting dari kontrak bisnis Islâm adalah untuk memastikan kemanfaatan kedua partner di dalam kontrak. Karena kontrak untuk organisasi bisnis atau proses produksi memiliki masalah seperti masalah principal- agen yang terstruktur secara top-down berkenaan dengan asymetri information dan moral hazard, maka ini dengan mudah bisa diminimalisasikan di dalam jenis kontrak Islâm.

Moral hazard disebabkan oleh asymetri information yang merujuk pada tingkatan dimana seorang bawahan (agent) memiliki lebih banyak informasi dari atasannya (principal) berkaitan dengan wilayah tanggung jawab bawahan. Agent umumnya bertanggung jawab untuk mencapai tujuan dari principal yang ditetapkan bagi dirinya, tergantung pada sistem pengendalian yang digunakan. Agent juga bertanggung jawab untuk menggunakan metode dan prosedur yang ditetapkan oleh principal. Asymetri information, oleh karenanya, akan merujuk pada suatu keuntungan pengetahuan yang dimiliki oleh bawahan baik dalam tujuan principal atau dalam hal bagaimana tujuan principal tersebut tercapai. Mengenai tujuan principal, agent menganggap bahwa dia memiliki informasi yang lebih baik untuk menilai kinerja dirinya. Berdasarkan fakta bahwa agent adalah orang yang beroperasi sehari-hari di lapangan, maka agent akan memiliki perasaan yang lebih baik mengenai tingkat kesulitan yang dikaitkan dengan pencapaian tingkat kinerja tertentu. Mengenai perilaku, agent merasa banwa dia juga memiliki pemahaman yang lebih baik mengenai hubungan antara variabel input dan hasil. Ini sebagian dikaitkan dengan agent yang terpisah secara fisik dari principal saat bekerja di lapangan. Sebagai tambahan, agent umumnya mengetahui lebih banyak dari principal tentang tingkatan pengetahuan produk dan pengetahuan pasar, serta keputusan takyik yang digunakan olehnya pada pekerjaan di dalam proses pencapaian tujuan principal.

Dalam kaitan ini, agency dapat diartikan sebagai mekanisme pelaksanaan di mana perusahaan produksi atau perusahaan bisnis adalah dikelola atau di jalankan. Pada dasarnya, fungsi agency adalah berhubungan dan di atur oleh modalitas kontrak. Agency cost adalah suatu faktor di bawah masing- masing jenis kontrak. Perbedaan 
kepentingan serta informasi yang tidak simetri diantara principal dengan agent mungkin menyebabkan hasil tergantunng kepada sifat dan kontrak kompensasi.

Dalam teori keagenan yang berkembang saat ini ada problem moral hazard yang timbul karena adanya asymetri information, yaitu manajemen memosisikan informasi yang superior untuk memaksimalkan kepentingan manajemen sendiri dan mengasumsikan bahwa shareholders tidak bisa mengobservasi perilaku manajemen. Moral hazard dapat dipecahkan dengan mendesain perjanjian kontrak dengan memberikan insentif kepada manajemen (bonus plan dan net income ) yang diungkapkan dalam laporan keuangan.

Pada dasarnya kontrak bisnis Islâm didasarkan pada pembahasan fiqh dari kelompok-kelompok pemikiran atau mazhab yang berbeda. Dalam kontrak bisnis Islâm, mudaraba atau agency dianggap sebagai cara yang paling penting yang melibatkan dua pihak atau lebih yang melakukan suatu kontrak dengan modal dan entrepreneurship guna melaksanakan suatu kerjasama (joint venture,) misalnya dalam bentuk perdagangan, bisnis, dan manufaktur. Semua bentuk kerja sama tersebut bertujuan untuk berbagi laba menurut rasio yang sudah ditentukan sebelumnya.

Dalam kerja sama tersebut yang menjadi permasalahan adalah bagaimana pengelolaan bisnis yang berbentuk syarî’ah dapat meminimalisir konflik kepentingan antara principal dan agen dengan suatu mekanisme pengawasan yang dapat mensejajarkan kepentingan-kepentingan yang terkait tersebut, sehingga kerja sama itu tidak banyak menimbulkan agency cost.

\section{Pencideraan Moral Hazard dan Agency Cost dalam Kontrak Bisnis Islâm}

Kesejahteraan ekonomi, sosial, dan keadilan ekonomi serta distribusi pendapatan dan kemakmuran yang adil adalah sasaran utama dari ekonomi Islâm. Komitmen yang kuat dari Islâm terhadap persaudaraan dan keadilan menjadikan kemakmuran (falah) umat manusia sebagai tujuan dasar dari Islâm. Untuk mencapai falâh (kemakmuran), ekonomi dan perbankan Islâm telah mengembangkan produk- produk investasi Islâm yang berbeda- beda. 
Di antara ajaran agama Islâm yang paling penting untuk menetapkan keadilan dan meghilangkan eksploitasi di dalam transaksi bisnis berdasarkan prinsip dasar syarî'ah dalam konteks figh al-mu'âmalah adalah larangan seluruh sumber kekayaan yang tidak sah. Tiga aspek dari elemen-elemen yang dilarang dalam kontrak, yang mungkin menyebabkan orang melakukan pengkayaan secara tidak sah adalah: Pertama, ribâ atau bunga. Berdasarkan pandangannya yang paling prinsip tentang status manusia di muka bumi, Islâm dengan tegas dan keras melarang segala bentuk praktek ribawi atau bunga uang. ${ }^{2}$

Berbagai pemikiran yang menyatakan bahwa pendapatan yang diperoleh dengan cara ribâ sah adalah jelas merupakan pendapat yang keliru dan menyesatkan karena praktik-praktik ribawi merupakan bentuk eksploitasi yang nyata. Islâm melarang ekspolitasi dalam bentuk apapun, apakah itu dilakukan oleh orang kaya terhadap orang miskin, oleh penjual terhadap pembeli, oleh majikan terhadap budaknya, oleh laki- laki terhadap wanita, maupun oleh atasan terhadap bawahannya. ${ }^{3}$

Menurut Ensiklopedi Islam Indonesia, ribâ atau al- rima merupakan tambahan uang atas modal yang dipinjamkan pada peminjam dengan cara yang tidak benar atau tidak sesuai dengan

2 Berkenaan dengan ribâ, al-Qur'ân surat al-Rûm: 39 menyatakan, "Dan apa- apa yang kamu berikan sebagai tambahan (Ribâ) untuk menambah harta manusia maka ribâ itu tidak menambah di sisi Allah". Namun demikian, pada prinsipnya, seluruh agama samawi juga menolak praktik-praktik ribawi. Sebagai contoh, hukum Masaic menyatakan, "Jika engkau meminjamkan uang kepada salah seorang dari umat-Ku,orang-orang miskin di antara kamu, maka janganlah engkau bertindak sebagai seorang kreditur terhadap mereka. Janganlah engkau membebani mereka bunga uang." Pada bagian lain disebutkan, "Jika seorang teman kamu pailit sehingga tidak dapat melunasi utangnya kepada kamu dan kamu menjadikannya sebagai budak belian janganlah kamu kenakan bunga terhadap uangnya atau yang sejenisnya". Lihat kitab Exodus Bab 22 ayat 25 dan kitab Leviticus bab 25 ayat 25, The Old testement (Chicago: Chicago University Pres, 1946), hlm. 71-114.

${ }^{3}$ Amir Hasan Siddiqi, Studies in Islâmic History, (Karachi: The Jamiyatul Falah Publications, 1962), hlm. 102.

${ }^{4} a l$-Ribâ atau al-rimâ makna asalnya ialah tambah, tumbuh dan subur;adapun pengertian tambah dalam konteks ribâ ialah tambahan uang atas modal yang diperoleh dengan cara yang tidak di benarkan syara', apakah tambahan itu berjumlah sedikit atau berjumlah banyak, seperti yang diisyratkan dalam al-Qur'ân. 
syariah Islâm. ${ }^{5}$ Ribâ atau bunga dilarang sepenuhnya didalam hukum Islâm. Ribâ adalah sumber keuntungan tidak sah yang menonjol, karena syarîah tidak menganggap uang sebagai suatu komoditi dimana harus ada harga atau penggunaannya. Uang adalah alat pertukaran di dalam suatu aset yang berorientasi ekonomi, dan sebagai penyimpangan nilai. Meskipun demikian, istilah ribâ atau bunga digunakan dalam syarî́ah dalam dua pengertian, yaitu ribâ alnasî̀ah dan ribâ al-fadl. Ribâ al-nasî̀'ah adalah melebihkan pembayaran barang yang dipertukarkan, diperjualbelikan atau dihutangkan karena diakhirkan waktu pembayarannya baik yang sejenis maupun tidak. ${ }^{6}$ Sedangkan ribâ al-fadl adalah pertukaran antar barang sejenis dengan kadar atau takaran yang berbeda, sedangkan barang yang dipertukarkan itu termasuk dalam jenis barang ribâwi.7

Kedua, gharâr atau keragu-raguan di dalam kontrak. Syarî'ah menentukan bahwa demi kepentingan kejujuran dan urusan yang transparan di dalam kontrak di antara pihak- pihak, maka pengkayaan yang tidak sah yang timbul dari ketidakpastian atas dasar- dasar yang penting dari kontrak adalah dilarang. Gharâr berasal dari penipuan/muslihat melalui pengabaian kontrak oleh satu pihak atau lebih. Berjudi juga merupakan bentuk gharâr karena penjudi mengabaikan hasil- hasil perjudian.

Terdapat beberapa jenis gharâr, yang kesemuanya haram. Contoh-contohnya adalah: (a) Menjual barang dimana penjual tidak mampu memberikan/ mengirimkannya; (b) menjual barang yang diketahui atau tidak diketahui dengan harga yang tidak diketahui, misalnya menjual isi dari kotak kardus yang tertutup; (c) menjual barang tanpa penjelasan yang sesuai, seperti pemilik toko menjual pakaian dengan ukuran yanng tidak pasti; (d) menjual barang tanpa menjelaskan harganya, misalnya menjual dengan " harga yang tengah berlaku"; (e) embuat kontrak yang tergantung pada suatu kejadian yang tidak di ketahui, misalnya di saat kawan saya tiba jika waktunya tidak dipastikan; dan (f) menjual barang berdasarkan penjelasan yang salah.

5. Karnaen Perwataatmadja, Bank dan Asuaransi Islâm di Indonesia, (Jakarta: Prenada Media Group, 2005), hlm. 25.

${ }^{6}$ Hendi Suhendi, Fiqh Muamalah, (Jakarta; Raja Grafindo Persada, 2005 ), hlm. 62.

7Muhammad Syafi'i Antonio, Bank Syariah dari Teori ke Praktek, (Jakarta: Gema Insani, 2001), hlm. 41. 
Untuk menghindari gharâr, maka para pihak yang berkontrak harus: (1) Memastikan bahwa ada barang dan harga, dan bisa diberikan/ dikirimkan; (2) menjelaskan karakteristik dan jumlah nilai nilai pembandingnya; (3) menjelaskan jumlah, kualitas dan tanggal pengiriman, jika ada.

Ketiga, maysîr atau berjudi/mengundi nasib. Ibrahim Hosen, sebagaimana dikutip oleh Suhendi, menyatakan bahwa hakikat judi menurut bahasa arab adalah permainan yang mengandung unsur taruhan yang dilakukan oleh dua orang atau lebih secara langsung (berhadap- hadapan) di dalam suatu majelis. ${ }^{8}$

Pada umumnya, kebanyakan para ulama mengharamkan lotere (undian) sekalipun hasil lotere tersebut digunakan untuk derma. Pasalnya, menurut kebanyakan ulama, derma yang diberikan ini tidak atas dasar keikhlasan, sedangkan dalam konteks Islâm, ikhlas merupakan salah sati masalah yang dianggap pokok. ${ }^{9}$ Larangan maysîr muncul dari premis bahwa kesepakatan diantara para pihak sesungguhnya adalah hasil dari dorongan amoral karena harapanharapan yang salah di benak para pihak bahwa mereka akan mendapatkan keuntungan yang tidak semestinya dari kontrak.

Sejumlah pengaturan barter yang tidak lazim bagi perdagangan pasar pra Islâm adalah di larang oleh nabi Muhammad saw. Karakteristik yang dimiliki oleh barter- barter tersebut adalah sama bahwa itu tergantung pada perkiraan atau definisi yang tidak pasti mengenai barang yang diperdagangkan. Dari larangan pengaturan barter yang demikian itu maka hukum Islâm membuat aturan yang keras mengenai definisi objek (bentuk) kontrak. Contoh- contoh kontrak yang dilarang adalah: Pertama, muzabana, yakni menjual buah yang basah dengan buah yang kering, seperti menjual padi kering dengan bayaran padi yang basah, sedangkan ukurannya dengan dikilo sehingga akan merugikan pemilik padi kering. Kedua, muhaqalah. Baqalah berarti tanah, sawah dan kebun, maksud Muhaqalah disini adalah menjual tanam- tanaman yang masih di ladang atau di sawah. Hal ini dilarang agama sebab ada persangkaan

\footnotetext{
8 Suhendi, Figh Mu'amalah, hlm. 318.

${ }^{9}$ Ahmad Hasan, Soal Jawab tentang Berbagai Masalah Agama, (Bandung: CV. Diponegoro, 1988), hlm. 367.
} 
ribâ di dalamnya. ${ }^{10}$ Ketiga, mulamasah, yakni kontrak penjualan zaman dulu di mana penjualan disepakati di mana pembeli atau penjual menyentuh sehelai pakaian. Keempat, munabudhah, yakni kontrak penjualan zaman dulu di mana penjualan disepakati di mana pembeli atau penjual melemparkan sehelai pakaian kepada yang lain.

Bilamana sifat dari seluruh kontrak bisnis adalah berbeda bentuknya satu sama lain, maka prinsip dasar dari syarî́ah mengenainya adalah hampir sama. Prinsip- prinsip dasar ini adalah:

a. Syarat dan kondisi kontrak kerjasama (joint venture) harus dirancang sedemikian rupa untuk menghindari adanya kemungkinan perselisihan selama pelaksanaan bisnis atau pada saat pembagian laba atau penangggungan rugi.

b. Modal bisnis harus dalam bentuk uang, jika seseorang atau beberapa partner adalah ikut serta di dalam menjalankan bisnis mereka atau komoditi atau properti nilai dari bisnis mereka, maka komoditi atau properti tersebut harus ditentukan dalam bentuk uang dan jumlah ini harus diperlakukan sebagai kontribusi partner tersebut.

c. Di dalam suatu kemitraan hubungan diantara para partner adalah sebagai principal/pokok dan agent.

d. Modal dan tenaga kerja serta dalam beberapa kasus goodwill dan kelayakan kredit adalah bertanggungjawab secara bersama- sama untuk menciptakan laba dan bertanggung- jawab secara bersamasama untuk berbagi laba. Dalam hal hanya satu faktor yang bertanggung- jawab untuk menciptakan laba maka itulah yang memenuhi syarat untuk mendapatkannya.

e. Hak dan kewajiban para partner tergantung pada sifat bisnis kerjasama dan diatur oleh adat istiadat, kesepakatan dan penggunaan. Dalam hal ini kepentingan terhadap bisnis tersebut adalah kriteria yang paling penting untuk menentukan hak dan kewajiban para rekanan.

f. Hak seiring dengan kewajiban. Jadi partner yang tidak aktif sekutu diam) mungkin tidak diijinkan untuk mengikat perusahaan dengan komitmennya. Para partner tidak akan menuntut return yang tetap atas pekerjaan mereka kecuali

10 Suhendi, Fiqh Mu'amalah, hlm. 79. 
pembagian laba, tetapi para pegawai akan menerima upah dari bisnis tersebut.

g. Didalam suatu bisnis kerjasama, produktifitas dan laba diukur berdasarkan modal yang diinvestasikan tetapi tenaga kerjalah yang perperan terhadap produktifitas dan laba. Jadi proporsi bagian partner di dalam modal semata tidak bisa menjadi faktor untuk menentukan bagian partner di dalam laba bisnis. Oleh karena itu, bagian laba tidak bisa disepadankan dengan bagian di dalam modal. Partner dengan kontribusi tenaga kerja yang lebih tinggi diberikan bagian laba yang lebih besar meskipun kontribusi modalnya mungkin kuranng dari yang lain.

h. Kerugian terjadi dalam hal modal gagal untuk berkembang dan berkurang. Jadi di dalam peristiwa kerugian, laba yang tidak dibayarkan kepada partner yang bekerja adalah kerugian tenaga kerja. Kerugian di dalam modal secara eksklusif ditanggung oleh modal tersebut. Melalui cara ini jika laba mungkin di distribusikan menurut kondisi- kondisi yang menentukan maka kerugian ditanggung oleh para partner secara proporsional sesuai dengan bagian mereka didalam modal bisnis.

i. Prinsip dasar yaitu laba beriringan dengan kewajiban. Dengan demikian, seorang partner yang sudah siap untuk memikul kewajiban akan memiliki bagian juga di dalam laba. Orang yang ikut ke dalam bisnis hanya untuk mengambil bagian di dalam laba tanpa berkontribusi sesuatu bagi bisnis dan tanpa menerima tanggung jawab apapun adalah tidak layak untuk mendapatkan laba.

j. Laba beriringan dengan resiko, tidak ada partner yang memiliki hak untuk menentukan proporsi laba yang tetap, yang menjamin dirinya sendiri untuk mendapatkan return yang pasti. Jika laba meningkat maka seluruh partner akan membaginya secara proporsional. Jika tidak ada laba maka tidak ada partner yang bisa mengambil bagian melalui hak eksklusifnya.

k. Kerugian yang timbul karena kelalaian akan dibebankan kepada partner yang bertanggung jawab terhadapnya.

1. Kewajiban partner akan tergantung pada sifat kerjasama.

Sifat dan Penggolongan Kontrak Bisnis Islâm. 
Bentuk resmi dari perusahaan atau kontrak bisnis Islâm adalah menjelaskan bagaimana modal didapatkan, bagaimana tenaga kerja dipekerjakan, bagaimana faktor- faktor di hargai, siapa yang membuat keputusan, bagaimana perusahaan atau kontrak dibubarkan, dan siapa yang menanggung resiko kegagalan. Jenisjenis kontrak bisnis dan organisasi yang digunakan sebelum dan selama waktu Nabî Muhammad SAW dan yang tidak beliau larang adalah diterima sebagai bentuk resmi perusahaan atau kontral Islâm. Oleh karena itu, syarî'ah Islâm memberikan berbagai jenis kontrak keuangan atau bisnis yang masing- masing memiliki fitur dan penggunaan yang berbeda-beda.

Kontrak bisnis Islâm bisa digolongkan menjadi tiga kategori umum, yaitu: Pertama, kontrak bisnis berdasarkan akomodasi keuangan langsung atau 'uqûd al- Isytirak yang mencakup pembagian laba, prinsip pembagian laba rugi, dan prinsip pembagian hasil. Kedua, kontrak bisnis berdasarkan akomodasi keuangan tidak langsung atau 'uqûd al-muawadlah, yang meliputi prinsip berdasar mark-up, prinsip berdasar sewa, dan prinsip pembelian kemudian. Ketiga, bentuk lain dari kontrak yang diperbolehkan adalah investasi langsung, pembiayaan pada ongkos pengembangan, pembagian sewa berdasarkan pembangunan/ pembelian rumah/flat, gedung, gudang, dan sebagainya berdasarkan kepemilikan bersama, investasi pelelangan, sindikat, dan pembiayaan konsorsium.

Akomodasi keuangan langsung dan prinsip pembagian laba itu sendiri dibagi ke dalam du bagian, yaitu: Pertama, mudlarabah, yakni perjanjian kerjasama antara pemilik modal (uang atau barang) dengan pengusaha (entrepreneur), di mana pemilik modal bersedia membiayai sepenuhnya suatu proyek/usaha dan pengusaha setuju untuk mengelola proyek tersebut dengan pembagian hasil sesuai dengan perjanjian. Pemilik modal tidak dibenarkan ikut dalam pengelolaan usaha, tetapi diperbolehkan membuat usulan dan melakukan pengawasan. Apabila usaha yang dibiayai mengalami keugian, maka kerugian tersebut sepenuhnya ditanggung oleh pemilik modal, kecuali apabila kerugian tersebut terjadi karena penyelewengan atau penyalahgunaan oleh pengusaha. ${ }^{11}$

11Warkum Sumitro, Asas-asas Perbankan Islâm dan Lembaga-lembaga Terkait, (Jakarta: Raja Grafindo Persada, 2004 ), hlm. 32. 
Terdapat dua jenis mudlarabah, yaitu: (1) Mudlarabah yang dibatasi. Dalam jenis ini, pemilik modal meminta partner kerja untuk berdagang melalui modalnya dan memberikan batasan-batasan tertentu yang berkaitan dengan jenis komoditas yang harus diperdagangkan, waktu perdagangan, tempat perdagangan, atau orang kepada siapa partner kerja tersebut harus berdagang. (2) Mudarabah yang tidak dibatasi. Dalam hal ini, partner kerja atau mudlârib bisa berdagang dalam segala komoditas (yang sah), dengan semua orang yang dianggap cocok tanpa dibatasi oleh periode waktu atau tempat yang tertentu.

Kedua, musyarakah, yakni akad kerjasama antara dua pihak atau lebih untuk suatu usaha tertentu di mana masing- masing pihak memberikan kontribusi dana (amal/expertise) dengan kesepakatan bahwa keuntungan dan resiko akan ditanggung bersama sesuai dengan kesepakatan. ${ }^{12}$

Musyarakah dibedakan ke dalam dua hal, ${ }^{13}$ yaitu syirkat al-milk atau musyarakah non kontrak dan syirkat al-uqûd. Musyarakah non kontrak ini mencakup: (a) syirkat al-milk bi al-ikhtiyâr (kemitraan sukarela); (b) syirkat al-milk bi al-zhâhir (kemitraan tidak sukarela).

Sedangkan syirkat al-'uqûd juga dibagi ke dalam beberapa bagian, yaitu: Pertama, syirkat al-inân, yakni kontrak antara dua orang atau lebih. Setiap pihak memberikan suatu porsi dari keseluruhan dana dan berpartisipasi dalam kerja. Kedua pihak berbagi dalam keuntungan dan kerugian sebagaimana yang disepakati di antara mereka. Akan tetapi, porsi masing- masing pihak, baik dalam dana, kerja maupun bagi hasil, tidak harus sama dan identik sesuai denga kesepakatan mereka. Ciri-ciri syirkah ini adalah berupa besarnya penyertaan modal dari masing- masing anggota harus sama dan masing- masing anggota berhak penuh aktif dalam pengelolaan perusahaan.

Kedua, syirkat al-mufawadlah, yakni kontrak kemitraan yang seimbang di mana modal, laba, dan rugi dibagi secara sama. Ciri-ciri syirkah ini adalah adanya kesamaan penyertaan modal masingmasing anggota, setiap anggota harus aktif dalam pengelolaan usaha,

\footnotetext{
12Ibn Rusyd, Bidâyat al-Mujtahid Wa Nihâyat al-Muqtashid, (Mesir: Musthafâ al-Halabi, 1988 ), hlm. 253- 257.

13 Sumitro, Asas-asas Perbankan, hlm. 36.
} 
dan pembagian keuntungan maupun kerugian dibagi menurut pangsa modal masing- masing.

Ketiga, syirkat al-wujûh, yakni kemitraan berdasar goodwill atau kemitraan kredit di mana bisnis dilakukan berdasarkan goodwill dan komoditas disewa/didapatkan berdasarkan kredit. Ciri-ciri syirkah ini adalah bahwa para anggota hanya mengandalkan wibawa dan nama baik mereka tanpa menyertakan modal, pembagian keuntungan maupun kerugian ditentukan menurut persetujuan.

Keempat, syirkat al-abdân, yakni bentuk bisnis kemitraan yang didasarkan tenaga kerja, skill, dan manajemen. Ciri-cirinya adalah bahwa usahanya berkaitan, menerima pesanan dari pihak ketiga, dan keuntungan dan kerugian dibagi menurut perjanjian.

Kategori kontrak bisnis Islâm yang kedua adalah kontrak bisnis berdasarkan akomodasi keuangan tidak langsung atau 'uqûd almuawadlah. Jenis kontrak ini mencakup tiga prinsip, yaitu: Pertama, prinsip berdasarkan mark-up atau murabahah. Ini adalah kontrak ditambah biaya di mana satu pihak ingin membeli peralatan atau barang dan komoditas dengan melakukan pendekatan kepada pihak lain untuk membeli item tersebut dan menjual kepadanya pada suatu biaya dan laba yang dinyatakan. Dengan metode kontrak ini, pihak yang memerlukan pembiayaan untuk membeli mesin atau peralatan bisnis mendapatkan pembiayaan yang diperlukannya dengan basis pembayaran tunda. Para petani mungkin juga mendapatkan berbagi input pertanian dari bank berdasarkan pembayaran tunda.

Kedua, prinsip pembelian kemudian . ini mencakup dua hal, yaitu (1) bay' al-salam, yakni pembayaran lanjut atau pembelian di waktu kemudian. Kontrak ini adalah penjualan suatu barang untuk dikirimkan kepada pembeli pada tanggal di masa yang akan datang, yang ditetapkan di waktu kontrak. Ini adalah kontrak transaksi dagang dan bukannya kontrak pinjaman. Jenis pembiayaan ini paling serinng digunakan ketika manufakture memerlukan modal untuk memanufaktur produk akhir bagi pembeli. Sebagai return terhadap pembayaran pada waktu kemudian, pembeli menerima harga yang lebih menguntungkan, yaitu dibaginya margin laba dengan manufakturer. (2) Istisna pembiayaan progresif (berdasar kemajuan), yakni kontrak pemrolehan barang melalui spesifikasi atau order di mana harga dibayarkan secara progresif sesuai dengan kemajuan pekerjaan. Contohnya adalah pembelian rumah yang akan dibangun, 
yaitu pembayaran akan dilakukan kepada pengembang atau pembangun menurut tahap pekerjaan yang telah diselesaikan.

\section{Implikasi Masalah Agency dalam Kontrak Islâm.}

Dari perspektif ilmiah literatur pembiayaan perusahaan, keuntungan yang jelas dari perbankan Islâm adalah kemampuannya yang lebih besar untuk mengalokasikan resiko secara optimal melalui pemabgian return proyek diantara pemilik modal dengan entrepreneur. Terlepas dari manfaat positif pembagian resiko ini, perbankan Islâm atau PLS (Profit and Loss Sharing) juga menghadapi masalah principal- agent yang berat yang timbul dari informasi yang asimetri dan pengawasan yang berbiaya mahal. Masalah-masalah tersebut adalah: Pertama, bank yang sedemikian akan menghadapi kesulitan yang diakibatkan oleh keterbatasan informasi dari luar dan kemungkinan kesuksesan proyek yang tidak bisa diberikan kepada bank secara kredibel, karena setiap pelamar PLS (Profit and Loss Sharing) akan menyatakan kualitasnyalah yang terbaik. Kesulitan bank di dalam menentukan kualitas pinjaman pelamar menghasilkan berbagai masalah pemilihan yang merugikan terutama ketika pembiayaan utang adalah tersedia dari sumber- sumber saingannya. ${ }^{14}$ Peminjam yang memperkirakan proyek mereka akan memberikan keuntungan non keuangan yang tinggi tetapi laba yang terelisasi adalah rendah akan memilih pembiayaan PLS karena mereka akan menikmati return total yang tinggi pada biaya modal yang rendah.

Kedua, dalam kontrak PLS, peminjam memiliki setiap insentif untuk kurang melaporkan (under-report) atau mengurangi laba yanng mereka nyatakan. Mereka bisa menaikkan laba dengan mengambil tambahan laba yang berlebihan atau waktu senggang ekstra atau memakai dalih akuntansi. Oleh karena itu, bank- bank Islâm harus mengeluarkan biaya pengawasan yang mahal untuk memastikan bahwa laba yang dinyatakan adalah cerminan yang sesungguhnya ataukah tidak dari aktifitas-aktifitas perusahaan atau proyek bisnis. Asymetri information ex-post ini menyebabkan bank-bank Islâm menghadapi masalah kejahatan moral.

${ }^{14}$ Mills P. and Presley J. R, Islamic Finance; Theory and Practice, (Macmillan: Forthcoming, 1998), hlm. 87. 
Ketiga, kerentanan bank Islâm terhadap kejahatan moral dan seleksi yang merugikan kemungkinannya tidak bisa membuatnya bersaing dengan bank yang konvensional, karena biaya tambahan di dalam pengumpulan informasi dan penilaian proyek, mengurangi insentif kerja bagi bagi entrepreneur dan biaya produksi yang lebih tinggi.

Beberapa peneliti melihat mengapa diversifikasi tidak menciptakan nilai, dan beberapa perusahaan melakukan divestasi terhadap unit bisnis untuk melakukan fokus pada core bisnis. Bahwa diversifikasi tidak hanya dipandang dari motivasi manajerial untuk menghasilkan sinergi dan motif ekonomi. Ternyata kegagalankegagalan diversifikasi dicermati oleh beberapa peneliti disebabkan adanya konflik agency, asymetri information dan moral hazard. Teori ini lebih menekankan pada aspek perilaku dala sistem pengendalian manajemen.

Teori agency dapat menjelaskan bahwa perusahaan melakukan diversifikasi untuk mengurangi resiko, termasuk di dalamnya memasuki lini bisnis yang berbeda. Argumentasi yang sering adalah pemegang saham tidak memperoleh manfaat langsung dari pengurangan resiko diversifikasi perusahaan. Jika terjadi asymetri information antara perusahaan dan investor potensial yang begitu besar perusahaan dapat memutuskan untuk ke NPV positif. Melalui diversifikasi manajer akan menciptakan pasar modal internal yang mana akan menimbulkan masalah asymetri information.

Menurut Sarker ${ }^{15}$ alasan diversifikasi dapat meningkatkan agency problem antara manajer dan shareholders juga diperdebatkan. Nilai strategis dari diversifikasi dalam hubungannya dengan agency tidak diturunkan dari pengaruh terhadap resiko akan tetapi dari pengaruh informasi principal tentang tindakan agent. Sebagai contoh bahwa aktivitas diversifikasi dapat meningkatkan atau menurunkan informasi principal, tergantung pada struktur informasi dari aktifitas tersebut. Dalam mengevaluasi bentuk alternatif organisasi perusahaan dengan aktifitas agent, pemilik secara potensial berhati-

\footnotetext{
15Sarker A.A, The Islâmic Banking: Principles and Operational Methodology, (Bangladesh: Research Departement and Monetery Management \& Technical Unit of Bangladesh Bank and Financial Sector Reform Project (FSRP) of the World Bank, 1993), hlm. 65
} 
hati terhadap return, riskness dan informativeness. Menurut Rogers, 16 diversifikasi mengurangi masalah asymetri information terhadap penjualan saham. Potensi biaya yang timbul dari diversifikasi adalah masalah agency di mana perusahaan yang melakukan diversifikasi kurang efisiennya kebijakan investasi pada perusahaan yang melakukan diversifikasi dibandingkan fokus. Sebagai alternatifnya perusahaan cenderung untuk lari dari manajer yang mempunyai kecenderungan untuk melakukan investasi berlebihan. Jika perusahaan yang melakukan diversifikasi untuk menghabiskan dananya pada proyek relatif lebih sedikit dan jika pasar memandang penawaran equitas sebagai indikasi bahwa perusahaan akan menginvestasikan dalan proyek yang murah dan mengharapkan pasar akan menjadi negatif terhadap pengumuman bahwa perusahaan yang melakukan diversifikasi mencari modal keuangan baru.

Solusi untuk Mengatasi Masalah Agency di dalam Perbankan Islâm.

Dengan memasukkan pertimbangan perilaku yang diabaikan di dalam kontrak, maka masalah principal dan agent bisa dipecahkan di dalam sistem perbankan PLS, dikarenakan reward yang dikaitkan untuk bekerjasama mungkin menyebabkan agent untuk bertindak secara jujur. Beberapa peneliti berpendapat bahwa untuk dua alasan, maka masalah principal-agent tidak akan mempengaruhi ekonomi Islâm. Pertama, umat muslim meyakini dalam konsep hidup, bahwa kejujuran akan dibalas dan ketidakjujuran akan di hukum. Ini adalah insentif non materi bagi orang- orang untuk bertindak jujur. Kedua, jika seluruh operasi keuangan adalah di dasarkan pada pembagian (dan hubungan yang kontinyu di kembangkan di antara penyandang dan enterpreneur, bukan hubungan satu waktu), maka entrepreneur yang jujur akan memaksa enterpreneur yang tidak jujur untuk hengkang dari pasar.

Format kontrak harus dirancang untuk bisa dijalankan dengan jujur. Selain itu, ia juga harus memasukkan mekanisme insentif tertentu, seperti memberi tempat di dalam kepemilikan, mengaitkan

16Mark Rogers, The Role of Diversification on Firm Performance, (Melbourne: Institute Working Paper, 2000), hlm. 34. 
transfer kepemilikan melalui bonus atas kinerja, membangun skema cadangan untuk membujuk guna tetap memegang saham perusahaan, dan ketentuan bagi pembayaran berkaitan dengan laba yang dikaitkan dengan pernyataan laba.

Penebusan PLS kembali bisa digunakan secara efektif untuk memomosikan entrepreneur dan proyek. Bank Islâm bisa melakukan proyek dengan entrepreneur infant dan secara bertahap mentransfer kepemilikan mereka sendiri dalam kasus mudlarabah dan secara parsial atau kepemilikan bersama dalam kasus musyarakah (bisa disebut mudlarabah yang menurun atau musyarakah yang menurun) kepada entrepreneur. Proses penebusan ini bisa memberikan insentif untuk mengurangi masalah kejahatan modal dari bank- bank Islâm.

Hubungan jangka panjang bank peminjam akan meningkatkan efisiensi perbankan PLS dalam cara yang lain. Contoh, interaksi yang berulang- ulang akan mengurangi biaya pengawasan saat bank menjadi terbiasa dengan sistem audit peminjam, dan menangani transaksi mereka pada periode yang diperpanjang, bank oleh karenanya bisa membuatpendapat yang lebih akurat mengenai kinerja peminjam dibandingkan dengan perusahaan yang lain dalam keadaan yang serupa dan mampu secara lebih baik untuk mengatakan bahwa return yang dilaporkan rendah adalah hasil dari ketidakefisienan peminjam.

Secara aktif melakukan pengawasan kredit melalui sistem perbankan cabang adalah suatu peluang untuk meminimalkan ketidaksimetrisan informasi yang dihasilkan jarak yang jauh. Pejabat kredit bank Islâm jika mereka bekerja dan tinggal di sekitar peminjam, maka akan memampukan mereka untuk meningkatkan reputasi mereka dan mengawasi operasi secara lebih mudah dan lebih dekat, maka masalah agency bisa diminimalkan. Meskipun itu akan meningkatkan beberapa biaya pengawasan, namun itu adalah situasi yang lebih baik dari pada kreditnya macet.

\section{Batasan-batasan Perusahaan Islâm.}

Pencapaian falâh atau kemakmuran menurut syarî'ah adalah fokus utama dari aktifitas manusia di dunia. Jadi, produsen Islâm, seperti halnya konsumen Islâm, akan mencoba untuk memaksimalkan falâh-nya di dunia ini. Oleh karenanya, produsen 
Islâm secara etik terikat oleh aktifitas produktif yang sesuai dengan tujuan syarî́ah.

Proses produksi di dalam perusahaan Islâm harus diatur oleh aturan etika emas syarî́ah, yaitu: (1) Maksimalisasi utilitas sosial dari kepentingan umat (mashlahah); (2) larangan kecelakaan yang terjadi atau menyebabkan kesedihan bagi orang lain (lâ dlarâr wa lâ dlirâr) atau minimalisasi disutilitas sosial (mafsadah); (3) keutamaan manfaat sosial dari pada manfaat pribadi, memberi kehidupan bagi orang lain dan membantu kesulitan dan kesempitan mereka terutama pada kondisi yang memaksa dan kebutuhan yang harus di penuhi. Oleh karena itu, perilaku produsen Islâm yang rasional akan dimotivasi oleh norma- norma ini.

Berkenaan dengan ini, karakteristik dasar dari perusahaan Islâm adalah: (1) Perusahaan Islâm terikat oleh aturan etis syarî'ah untuk memberikan jumlah barang dasar yang memadai dengan harga yang rendah guna memampukan seluruh anggota masyarakat mendapatkan barang- barang yang sedemikian; (2) perusahaan Islâm diharapkan beroperasi pada tingkatan hasil di mana pendapatan total adalah sama dengan biaya total; (3) produsen Islâm mungkin menolak upah pasar yang berlaku sebagai ' seragam' dan menyesuaikan ke upah yang lebih tinggi yang dia anggap harus dilakukan; (4) kekuatan pendorong perusahaan adalah kerjasama dan tanggung jawab satu sama lain dengan tenaga kerja dan modal serta entrepreneur dengan modal; (5) prinsip kontrak seperti mudlarabah, musyarakah, bay' al-salam, Istisna harus terbebas dari ribâ, gharâr dan maysîr; (6) hak dan tanggung jawab pihak-pihak yang melakukan kontrak harus ditentukan sebelumnya sebagai sifat dari pada kontrak.

\section{Penutup}

Kesimpulan dari pembahasan di atas adalah bahwa kontrak bisnis Islâm memiliki banyak bidang dan modalitas untuk diterapkan menurut kecocokan waktu, tempat dan lingkungan. Manfaat yang penting dari kontrak bisnis Islâm adalah untuk memastikan kemanfaatan kedua partner di dalam kontrak. Karena kontrak untuk organisasi bisnis atau proses produksi memiliki masalah seperti masalah principal-agent berkenaan dengan asymetri information dan kejahatan moral, maka ini dengan mudah bisa meminimalisasikan di 
dalam jenis kontrak Islâm. Berkenaan dengan teori perusahaan Islâm, mungkin diasumsikan bahwa mempertimbangkan seluruh kekuatan aktif internal dan eksternal di dalam fungsi perusahaan Islâm bahwa dapat memaksimalkan kesejahteraan sosial. Produsen berperilaku sebagai enterpreneur, yaitu memaksimalkan produksi dimana pendapatan total adalah sama dengan biaya total. Pendekatan kebutuhan dasar akan dianggap sebagai alat utama untuk mendesain rencana produksi di bawah proses shuratic. Agent akan diberi imbalan atas kejujuran dan kapablitasnya. Oleh karena itu, jika di dalam ekonomi Islâm, perusahaan Islâm menerapkan kontrak bisnis seperti yang dirancang dan disetujui oleh syarî'ah, maka masalah principalagent akan dapat diminimalisir dan masyarakat akan mendapatkan manfaat lebih banyak dari motif kemakmuran produsen dan agent pasar yang lain. Wa Allâh a'lam bi al-shawẩ.

\section{Daftar Pustaka}

Antonio, Muhammad Syafi'i. Bank Syariah dari Teori ke Praktik. Jakarta: Gema Insani, 2001.

Hasan, Ahmad. Soal Jawab tentang Berbagai Masalah Agama. Bandung: CV. Diponegoro, 1988

Mills P. and Presley J. R, Islamic Finance; Theory and Practice, (Macmillan: Forthcoming, 1998

Perwataatmadja, Karnaen. Bank dan Asuaransi Islâm di Indonesia. Jakarta: Prenada Media Group, 2005

Rogers, Mark. The Role of Diversification on Firm Performance. Melbourne: Institute Working Paper, 2000.

Rusyd, Ibn. Bidâyat al-Mujtahid Wa Nihâyat al-Muqtashid. Mesir: Musthafâ al- Halabi, 1988 
Sarker A.A, The Islâmic Banking: Principles and Operational Methodology, (Bangladesh: Research Departement and Monetery Management \& Technical Unit of Bangladesh Bank and Financial Sector Reform Project ( FSRP) of the World Bank, 1993.

Shiddiqi, Amir Hasan. Studies in Islâmic History. Karachi: The Jamiyatul Falah Publications, 1962

Suhendi, Hendi. Fiqh Muamalah. Jakarta: Raja Grafindo Persada, 2005.

Sumitro, Warkum. Asas-asas Perbankan Islâm dan Lembaga-lembaga Terkait. Jakarta: Raja Grafindo Persada, 2004 